\title{
Policy Analysis of Lecturer Performance in Participation in the Field of Research and Scientific Publications

\author{
(Study case at D-III and D-IV in Midwifery Poltekkes Kemenkes Medan)
}

\author{
Efendi Sianturi \\ Lecturer at Poltekkes Kemenkes Medan \\ North Sumatra, Indonesia \\ ssianturiefendi@gmail.com
}

\author{
Eka Daryanto \\ Lecturer at Universitas Negeri Medan \\ North Sumatra, Indonesia
}

\begin{abstract}
Lecturers are important elements that play a role in the Tri darma of higher education. Lecturers are professional educators with the main task of transforming, developing, and disseminating science, technology, and art through education, research, and community service. The purpose of this study was to determine the level of participation of lecturer performance and how to improve it in the Midwifery Poltekkes Kemenkes Medan. Poltekes Kemenkes Medan applied to aspects of research and publications. This research involved lecturers. Data obtained through in-depth interviews and analyzed. The results of this study indicate that lecturer participation in research increased but in terms of publication decreased in the Polytechnic Ministry of Health Medan majoring in Midwifery. For this reason, this research can motivate and increase the interest of all Medan Health Department lecturers at the Midwifery Department routinely holding proposal workshops, call of papers, and conferences as a result of research published in the form of books, proceedings, and scientific journals. In addition, research activities and publications carried out can increase the participation of lecturers in the field of research and publications as well as being an academic culture that is inherent in every lecturer of the Poltekes of the Ministry of Health in Medan majoring in DIII and DIV study programs.
\end{abstract}

Keywords- research; publication;lecturer; performance

\section{INTRODUCTION}

Higher education in Indonesia is growing very rapidly with growth over the past five years there has been a growth of 693 [1]. and now there are 3,151 universities. Of the many universities, as many as 3,068 are private universities, whereas state universities only total 83 . private universities can accommodate 2,298,830 students, while state universities can only accommodate as many as 907,323 students.

Decree of the Directorate of Higher Education SK DIKTI No. 152/E/T/2012 contains Publication of Scientific Work: "As we know that at the moment the total number of scientific works from Indonesian Universities in total is still low when compared to Malaysia, only around one seventh [2].

Based on the Tri Dharma component of higher education, a lecturer has three main tasks, namely: (1) implementing education; (2) conducting research; and (3) community service. Of the three components, research and publication are among the most difficult things to do because when lecturers obtain a decree, the lecturers' motivation and motivation to write their research results are then published in international scientific journals, the collaboration of lecturers with foreign parties in the field of research is individualized, and lack of financial support to facilitate quality research. Poltekkes Kemenkes Medan Department of Midwifery Study Program DIII and DIV, has optimally fulfilled the achievement of accreditation "B" supported by the performance of lecturers in each study program in the field of research and publication is the highest achievement lecturer performance of each study program well so that it gets the maximum value. The results of research works and publications in the Poltekkes of the Ministry of Health Medan, Department of Midwifery, Study Program, DIII and DIV are sufficient to meet accreditation, but the involvement of lecturers in the field of research and publication still needs to be increased, because the number of lecturers participating or contributing in the field of research and publications is not optimal. Therefore, the authors are interested in examining the performance of lecturers in the Polytechnic of the Ministry of Health, especially lecturers of the Study Program of DIII and DIV Midwifery in the field of research and publications who also contributed to the highest achievement.

The linkage of research implementation to education and community service can be seen in the benefits of research results. Article 46 states that the research results are useful for: enrichment of Science and Technology and learning; improving the quality of tertiary institutions and advancing the nation's civilization; increasing the independence, progress and competitiveness of the nation; fulfill the strategic needs of national development; and the transformation of Indonesian society into a knowledge-based society. Once the importance of the research is continued with scientific publications, the Government requires lecturers to do both of these things and has been regulated in Minister of Administrative Reform and Bureaucratic Reform Regulation Number 17 of 2013 concerning Lecturer Functional Position and Credit Numbers [2]. In the PAN \& RB Ministerial Regulation lecturers who 
wish to obtain an Academic Assistant Expert position, or promotion from an Expert Assistant to the Lector, or from the Head Lector must have scientific publications. For lecturers who have academic positions as Expert Assistants and Lectors, the handling of career management of their academic positions is delegated to the State University for lecturers to the Coordinator of Private Higher Education (Kopertis)/ Higher Education Service Institutions for tertiary lecturers private sector.

Minister of Research and Technology Dikti Number 20 Year 2017 which requires publication for Head Lecturers and Professors is in order to encourage increased quantity and quality of scientific publications at national and international levels. The increasing number of publications in international journals and reputable international journals will encourage Indonesia to be able to compete with other nations [3]. At present the number of Indonesian international publications is still below that of developed countries, even under Malaysia and Singapore.

\section{LITERATURE REVIEW}

\section{Policy Theory Policy in education}

Before discussing further about the implementation of education policy, it helps us discuss a little about public policy as an initial message to understand education policy and its implementation. Policies are often confused with wisdom. The main foundation underlying a policy is reason judgment. Of course, a policy is not simply the result of consideration of human reason. However, human reason is the dominant element in making decisions from various choices in policy decision making. Public policy according to [4] is a policy developed by government institutions and government officials who are influenced by non-government actors and factors. The purpose of this expression is that policies are not solely dominated by the interests of the government, actors outside the government must be considered for their aspirations, and influential factors must be reviewed beforehand. Policy is also a series of processes from a plan and formulation by a group or agency/government agency in the form of regulations or programs to solve a problem. According to [5], there are 3 (three) policy elements, namely policy actors, policy environment and public policy. Policy actors, such as citizen groups, labor unions, political parties, government agencies, elected leaders and policy analysts themselves. The policy environment, namely the specific context in which events surrounding the policy issue occur, influence and are influenced by policy makers contain dialectical processes, which means that the objective and subjective dimensions of policy makers are inseparable in practice.

The [4] author defines policy as a series of actions/activities proposed by a person, group or government in a particular environment where there are obstacles (difficulties) and opportunities for implementing the proposed policy in order to achieve certain goals.
Public Policy Lecturer Performance in Participation in the Field of Scientific Research and Publication According to [5] is a policy developed by government institutions and government officials who are influenced by non-government actors and factors. The purpose of this expression is that policies are not solely dominated by the interests of the government, actors outside the government must be considered for their aspirations, and influential factors must be reviewed beforehand6. Policy is also a series of processes from a plan and formulation by a group or agency / government agency in the form of regulations or programs to solve a problem.

According to [6], there are 3 (three) policy elements, namely policy actors, policy environment and public policy. Policy actors, such as citizen groups, labor unions, political parties, government agencies, elected leaders and policy analysts themselves. The policy environment, namely the specific context in which events surrounding the policy issue occur, influence and are influenced by policy makers contain dialectical processes, which means that the objective and subjective dimensions of policy makers are inseparable in practice.

\section{METHODOLOGY}

This type of research uses case study research. In this study the authors describe the performance of lecturers in the field of research and publications. The population in this study was a lecturer at the Department of Midwifery of D3 and D4 Poltekes Ministry of Health Ministry of Medan totaling 32 people including Head of Department. The research subjects used in this study were lecturers at the Department of Midwifery of D3 and D4 Poltekes Ministry of Health in Medan in terms of research and publications in 2015-2018.

To test the validity of the data obtained in the research to be conducted, researchers use informant review as the most commonly used method for increasing the validity of data in qualitative research [7]. Informant review is confirming data or interpretation to the informant so that an agreement is reached between the researcher and the informant.

\section{RESULT AND DISCUSSION}

Performance of Medan Ministry of Health Polytechnic Lecturers in Midwifery Study Program of DIII and DIV Midwifery in the Field of Research and Publication

TABLE 1. NUMBER OF LECTURERS IN THE POLTEKKES KEMENKES MEDAN STUDY PROGRAM DIII AND DIV MIDWIFERY IN 2016-2018

\begin{tabular}{|c|c|c|c|c|}
\hline \multirow{2}{*}{ Research } & \multicolumn{3}{|c|}{ Year } & Total \\
\cline { 2 - 5 } & 2016 & 2017 & 2018 & 25 \\
\hline $\begin{array}{c}\text { Study Program } \\
\text { DIII }\end{array}$ & 7 & 8 & 10 & 27 \\
\hline $\begin{array}{c}\text { Study Program } \\
\text { DIV }\end{array}$ & 8 & 9 & 10 & 27 \\
\hline
\end{tabular}

The table above can be explained that, if seen from each study program of DIII and DIV Midwifery from 2016 to 2018 , 
lecturers from the DIII and DIV Midwifery program conducted the most DIV program research: 27 researches followed by DIII program research.

TABLE 2. NUMBER OF LECTURER PUBLICATIONS BASED ON DIII STUDY PROGRAM AND D-IV STUDY PROGRAM POLTEKKES KEMENKES MEDAN MAJORING IN MIDWIFERY IN 2016-2018

\begin{tabular}{|c|c|c|c|c|}
\hline Research & \multicolumn{3}{|c|}{ Year } & \multirow{2}{*}{ Total } \\
\cline { 2 - 5 } & 2016 & 2017 & 2018 & 20 \\
\hline $\begin{array}{c}\text { Study Program } \\
\text { DIII }\end{array}$ & 8 & 6 & 6 & 25 \\
\hline $\begin{array}{c}\text { Study Program } \\
\text { DIV }\end{array}$ & 8 & 8 & 9 & 25 \\
\hline
\end{tabular}

From the above table it can be explained that, the publication of each DIII and DIV Midwifery Study Program from 2016 to 2018, lecturers from the DIII and DIV Midwifery study program which most did the DIV study program publication, followed by the Midwifery DIII study program. However, when viewed from the year of publication, in 2016 up to 2018 the number of publications made by lecturers of the Midwifery Study Program and DIV Study Programs decreased.

TABLE 3. NUMBER OF PUBLICATIONS AND RESEARCH IN THE POLTEKKES KEMENKES MEDAN STUDY PROGRAM DIII AND DIV MIDWIFERY DEPARTMENT IN 2016-2018

\begin{tabular}{|c|c|c|c|c|}
\hline \multirow{2}{*}{ Research } & \multicolumn{3}{|c|}{ Year } & \multirow{2}{*}{ Total } \\
\cline { 2 - 5 } & 2016 & 2017 & 2018 & \\
\hline Research & 20 & 23 & 24 & 67 \\
\hline Publication & 15 & 10 & 9 & 34 \\
\hline
\end{tabular}

Table 3. can be explained that during 2016 to 2018 the number of publications and research conducted by lecturers the number of publications and research conducted by lecturers of Study Program DIII and DIV Midwifery decreased.

TABLE 4. INVOLVEMENT OF POLTEKKES LECTURERS IN THE POLTEKKES KEMENKES MEDAN STUDY PROGRAM DIII AND MIDWIFERY DIV RESEARCH FIELD IN THE FORM OF\% 2016-2018

\begin{tabular}{|c|c|c|c|c|}
\hline $\begin{array}{c}\text { Study } \\
\text { Program }\end{array}$ & $\begin{array}{c}\text { Number } \\
\text { of } \\
\text { Lecturers }\end{array}$ & 2016 & 2017 & 2018 \\
\hline DIII & 13 & $\begin{array}{c}11 \\
(85 \%)\end{array}$ & $12(92 \%)$ & $\begin{array}{c}12 \\
(100 \%)\end{array}$ \\
\hline DIV & 19 & $\begin{array}{c}10 \\
(53 \%)\end{array}$ & $17(89 \%)$ & $18(94 \%)$ \\
\hline
\end{tabular}

From the above table it can be explained that the involvement of DIII and DIV Midwifery Study Program lecturers in the field of research of each study program increases.
TABLE 5. INVOLVEMENT OF LECTURERS POLTEKKES KEMENKES MEDAN STUDY PROGRAM DIII AND DIV MIDWIFERY IN THE FIELD OF PUBLICATION IN THE FORM OF PERCENT

\begin{tabular}{|c|c|c|c|c|}
\hline $\begin{array}{c}\text { Study } \\
\text { Program }\end{array}$ & $\begin{array}{c}\text { Number } \\
\text { of } \\
\text { Lecturers }\end{array}$ & 2016 & 2017 & 2018 \\
\hline DIII & 13 & $3(23 \%)$ & $4(30 \%)$ & $4(30 \%)$ \\
\hline DIV & 19 & $1(5 \%)$ & $2(10 \%$ & $2(10 \%)$ \\
\hline
\end{tabular}

From the above table, it can be explained that the involvement of DIII and DIV Midwifery Study Program lecturers in the field of publication of each study program decreases.

TABLE 6. INTENSITY OF LECURER OF POLTEKKES KEMENKES STUDY PROGRAM DIII AND DIV MIDWIFERY INVOLVED MORE THAN ONE STUDY EACH YEAR BASED ON STUDY PROGRAMS YEAR 2016-2018

\begin{tabular}{|c|c|c|c|c|}
\hline $\begin{array}{c}\text { Study } \\
\text { Program }\end{array}$ & $\begin{array}{c}\text { Number of } \\
\text { Lecturers }\end{array}$ & 2016 & 2017 & 2018 \\
\hline DIII & 13 & $0(0 \%)$ & $2(15 \%)$ & $2(15 \%)$ \\
\hline DIV & 19 & $0(0 \%)$ & $1(1 \%$ & $1(1 \%)$ \\
\hline
\end{tabular}

The above table can explain that the intensity of DIII and DIV Midwifery Study Program lecturers involved from one study of each study program was mostly conducted by the Midwifery DIII program, while the Midwifery DIV study program had the lowest intensity.

TABLE 7. INTENSITY OF POLTEKKES KEMEKES MEDAN STUDY PROGRAM DIII AND DIV MIDWIFERY WHICH PUBLISHES MORE THAN ONE PUBLICATION EVERY YEAR BASED ON 2016-2018 STUDY PROGRAM

\begin{tabular}{|c|c|c|c|c|}
\hline $\begin{array}{c}\text { Study } \\
\text { Program }\end{array}$ & $\begin{array}{c}\text { Number of } \\
\text { Lecturers }\end{array}$ & 2016 & 2017 & 2018 \\
\hline DIII & 13 & $0(0 \%)$ & $2(15 \%)$ & $2(15 \%)$ \\
\hline DIV & 19 & $0(0 \%)$ & $1(1 \%$ & $1(1 \%)$ \\
\hline
\end{tabular}

From the above table it can be concluded that the DIII and DIV Midwifery programs involved more than one publication with the most results. In the D III Midwifery Program 2017 and 2018, which gaps cause a decline and what motivation can give rise to interest as a way out for more enthusiasm in publication.

\section{CONCLUSION AND RECOMMENDATION}

A. Conclusion

1) The performance of lecturers in DIII and DIV Midwifery Study Programs in the field of research and publication for each study program is sufficient for the needs of accreditation.

2) Participation in the field of research is only $15 \%$ of the Midwifery Diploma Program, 5\% of the Midwifery DIV Study Program. The level of lecturer participation in the field of publication is only $4 \%$ in the Midwifery Diploma Program, $2 \%$ in the Midwifery DIV Program 
3) Lecturers in the Study Program and the Midwifery DIV which publish more than one study each year are still low.

4) DIII and DIV Midwifery Study Program lecturers who publish more than one publication each year are still low.

\section{B. Suggestion}

Based on the conclusions above, the suggestions given by the author to educational institutions and lecturers are:

1) Polytechnic Ministry of Health Study Program DIII and DIV Midwifery Department has a master plan of research in each study program

2) Each lecturer has a clear research road map in accordance with the research master plan has existed before;

3) The Ministry of Health Polytechnic Lecturer has a target of research and publication every year through the number of publications conducted by the Poltekkes Kemenkes Medan lecturers.

4) Monitoring and evaluation needs to be done every month following up the work meetings at the Poltekkes Kemenkes Medan and each study program.

5) Need to continue and increase the reward and apply punishment in accordance with the rules in force at the Poltekkes KemenkesMedan.

\section{ACKNOWLEDGMENT}

I should grateful to Poletkkes Kemenkes Medan for supporting me to give data and response to complete this research. And and also special thanks to dr. Eka Daryanto in leading me to set this reasearch. I am grateful to all of those with whom I have had the pleasure to work during this and other related projects. Each of the members of my Aisteel Committee at UNIMED 2019 has provided me extensive personal and professional guidance and taught me a great deal about both scientific research and life in general

\section{REFERENCES}

[1] DIKTI. 2009. Perspektif Perguruan Tinggi di Indonesia Tahun 2009. http://www.unud.ac.id/ind/wpcontent/uploads/perspektif-ptindonesia2009.pdf

[2] Direktorat Jenderal Pendidikan Tinggi. 2013. Panduan Pelaksanaan Penelitian Dan Pengabdian Kepada Masyarakat Di Perguruan Tinggi Edisi IX. Direktorat Penelitian dan Pengabdian kepada Masyarakat: Jakarta.

[3] Direktorat Jenderal Pendidikan Tinggi. 2005. Praktek Baik dalam Penjaminan Mutu Perguruan Tinggi, Penelitian dan Publikasi. Departemen Pendidikan Nasional: Jakarta.

[4] Hamzah, dkk. 2010. "Sistem Pendukung Keputusan Penilaian Kinerja Dosen Dengan Metode Balance Scorecard". Seminar Informatika 2010 UPN Veteran Yogyakarta 22 Mei 2010, ISSN: 1979-2328

[5] Hutchinson, S. R., \& Lovell, C. D. (2004). A Review of methodological characteristics of research published in key journals in higher education: implications for graduate research training. Research in Higher Education, 45(4), 383-403. https://doi.org/10.1023/B:RIHE.0 000027392.94172.d2

[6] Retnowati, T. H., Mardapi, D., Kartowagiran, B., \& Suranto, S. (2017). Model evaluasi kinerja dosen: pengembangan instrumen untuk mengevaluasi kinerja dosen. Jurnal Penelitian Dan Evaluasi Pendidikan, 21(2), 206. https://doi.org/10.21831/pep.v21 i2.16626

[7] Sukirno. (2017). Modeling academic professional performance in higher education. International Journal of Environmental and Science Education - IJESE, 12(8). Retrieved from http://www.ijese.net/makale/193 3 